\title{
Evaluation of Laboratory risk indicators (LRINEC Sore) for early diagnosis and prognosis in necrotizing fasciitis.
}

\author{
Bansal N. ${ }^{1 *}$, Garg N. ${ }^{2}$ \\ DOI: https://doi.org/10.17511/ijoso.2020.i03.07 \\ 1* Neeraj Bansal, PG Resident, Department of General Surgery, Peoples College of Medical Sciences and Research Centre, Bhopal, Madhya \\ Pradesh, India. \\ 2 Nitin Garg, Professor and HOD, Department of General Surgery, Peoples College of Medical Sciences and Research Centre, Bhopal, \\ Madhya Pradesh, India.
}

Background: Necrotizing soft tissue infections are rare but potentially fatal involving subcutaneous tissues and fascia. It can progress to systemic inflammatory response syndrome (SIRS), shock, potential limb loss and death. The present study is an attempt to evaluate the early diagnostic efficacy and prognostic value of laboratory risk indicators (LRINEC scoring system) in necrotizing fasciitis. Methods: This prospective observational study was conducted onall patients of 18-80year age admitted in the Department of Surgery, PCMS and RC during the study period presenting with any of the clinical features of soft tissue infections.LRINEC SCORE was calculated for each patient using the laboratory values (CRP, WBC, $\mathrm{Hb}$, sodium, creatinine and glucose) that ranged from 0 13 Record was made of the final diagnosis and prognosis. Diagnostic and prognostic value of LRINEC score was evaluated using statistical analysis. Results: The most common site involved was Lower Extremities followed by Upper and Scrotum/Perineum. The study revealed that risk increases with advancing age. The systemic complication was in the intermediate and high-risk case, no one in lowrisk case. The conservative treatment was mainly used for the patients with low risk but the surgical intervention was the mainstay of management in the intermediate and high-risk category. Conclusion: In the present study it can be concluded that LRINEC score, using readily available laboratory data, can serve as a simple and an important tool in predicting the prognosis and risk stratification in cases of necrotizing fasciitis but diagnostic efficacy is not that much reliable.

Keywords: Necrotizing Fasciitis, LRINEC Score, Soft Tissue Infection, Fasciotomy

\section{Corresponding Author}

Neeraj Bansal, PG Resident, Department of General Surgery, Peoples College of Medical Sciences and Research Centre, Bhopal, Madhya Pradesh, India. Email: neeraj.grmc12@gmail.com

\section{How to Cite this Article}

Bansal N, Garg N. Evaluation of Laboratory risk indicators (LRINEC Sore) for early diagnosis and prognosis in necrotizing fasciitis.. Surgical Rev Int J Surg Trauma Orthoped. 2020;6(3):181-188. Available From

https://surgical.medresearch.in/index.php/ijoso/artic le/view/190
To Browse

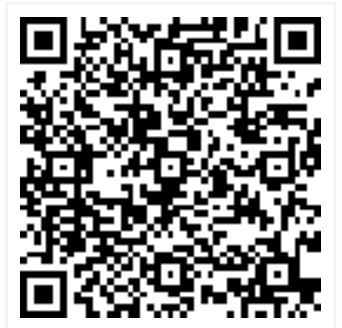

Manuscript Received 2020-06-10

Conflict of Interest No
Review Round 1 2020-06-20

Funding

$\mathrm{Nil}$

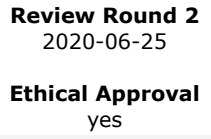

Review Round 3

Plagiarism X-checker $9 \%$
Accepted 2020-06-29

Note

(c) 2020 by Neeraj Bansal, Nitin Garg and Published by Siddharth Health Research and Social Welfare Society. This is an Open Access article licensed under a Creative Commons Attribution 4.0 International License https://creativecommons.org/licenses/by/4.0/ unported [CC BY 4.0]. 


\section{Introduction}

Necrotizing soft tissue infections often are mistaken for cellulitis or wound infections and hence, diagnostic delay. Despite advances in antibiotic therapy and intensive care, the mortality of necrotizing soft tissue infections is still high.

This rare disease can be caused by more than one type of bacteria but group A streptococcus is considered the most common cause of NF [1]. Features of necrotizing fasciitis include haemorrhagic purpura, subcutaneous bleeding, bullae, necrosis and gangrene.

The Laboratory Risk Indicator for Necrotizing Fasciitis (LRINEC) score was first proposed by Wong et al [2]. utilizing 6 laboratory variables that are routinely measured to assess soft tissue infections that enabled the categorization of patients into lowrisk, intermediate-risk, and high-risk groups.

A score of 6-7 meant $50 \%-75 \%$ risk of NF whereas any score more than 8 is a high indicator to more than $75 \%$ risk [2].

The major prognostic determinants like systemic complications, duration of hospital stay and mortality can be reduced by early recognition, aggressive debridement of necrotic tissues, early commencement of intravenous antibiotics [3].

All the parameters needed for the calculation of the score are readily available in the emergency department at the 'bedside' [2].

The major prognostic determinants like systemic complications, duration of hospital stay and mortality can be reduced by early recognition, aggressive debridement of necrotic tissues, early commencement of intravenous antibiotics.

The present study is an attempt to evaluate the early diagnostic efficacy and prognostic value of laboratory risk indicators (LRINEC scoring system) in necrotizing fasciitis.

\section{Methods}

Duration and type of study: November 2017 to April 2019 and Prospective longitudinal and observational study.

Sampling: All the patients of soft tissue infections meeting the inclusion and exclusion criteria during the study period were randomly selected.

Source of data: Patients with soft tissue infections
Admitted in the Department of Surgery, PCMS and RC.

Inclusion criteria: Patients of age group 18-80 years with severe soft tissue infections.

\section{Exclusion criteria:}

- Patients $<18$ years of age.

- Patient referred to other institution.

- Patient with surgical site infections.

- Patients not giving consent for the study.

- Patients having localized infection only in the form of an abscess.

- Patients in whom LRINEC score cannot be calculated due to lack of investigation data.

\section{Methodology and data collection}

- All patients of $18-80$ year age admitted in the Department of Surgery, PCMS and RC during the study period presenting with any of the clinical features of soft tissue infection such as swelling, pain, skin changes were enrolled in the study. A detailed history and physical examination were done as per the All the patients were subjected to following investigations(CRP, WBC, HB, sodium, creatinine, glucose). LRINEC SCORE was calculated for each patient using the above laboratory values that ranged from 0-13.

- Based on the LRINEC score, patients were grouped in low, intermediate, and high-risk groups. The record was made of the final diagnosis, treatment given, an operative procedure performed, complications, outcome and duration of hospital stay.

- The prognosis was defined on the basis of systemic complications, recovery and length of hospital stay, tissue loss and treatment given. Diagnostic and prognostic value of LRINEC score was evaluated using statistical analysis.

Ethical approval institutional and research review board approval was obtained from Peoples College of Medical Sciences and Research Centre, Bhopal for conducting this research in the institute.

Statistical analysis: Simple descriptive statistics with mean, mode, median, range, and percentage were used for analysis.

A P-value of less than 0.5 was considered significant and a $\mathrm{p}$-value less than 0.01 was considered highly significant. 


\section{Result}

Table-1: LRINEC risk score.

\begin{tabular}{|l|l|l|l|}
\hline \multicolumn{1}{|c|}{ LRINEC Score } & Frequency & Percent $(\%)$ & \multicolumn{1}{c|}{ Risk } \\
\hline$<6$ & 26 & 43.3 & Low \\
\hline $6-8$ & 24 & 40.0 & Intermediate \\
\hline$>8$ & 10 & 16.7 & High \\
\hline Total & 60 & 100.0 & \\
\hline
\end{tabular}

Patients were categorized into different risk groups using the LRINEC score. On the basis of those patients having LRINEC score $<6$ were categorized as low risk, $6-8$ as intermediate risk, and $>8$ as high risk.

Table-2: Age of patients with an LRINEC risk score.

\begin{tabular}{|l|l|l|l|l|l|}
\hline \multirow{2}{*}{ Age of patients } & \multicolumn{3}{|c|}{ LRINEC Score Risk } & \multirow{2}{*}{ Total } & \multirow{2}{*}{ p-value } \\
\cline { 2 - 5 } & Low & Intermediate & High & & \\
\hline$<30$ & $7(26.9)$ & $0(0)$ & $0(0)$ & $7(11.7)$ & \\
\hline $31-40$ & $9(34.6)$ & $8(33.3)$ & $0(0)$ & $17(28.3)$ & \multirow{2}{*}{$<0.001$} \\
\hline $41-50$ & $5(19.2)$ & $5(20.5)$ & $2(20.0)$ & $12(20.0)$ & \\
\hline $51-60$ & $5(19.2)$ & $9(37.5)$ & $3(30.0)$ & $17(28.3)$ & \\
\hline $61-70$ & $0(0)$ & $2(8.3)$ & $1(10.0)$ & $3(5.0)$ & \\
\hline $71-80$ & $0(0)$ & $0(0)$ & $4(40.0)$ & $4(6.7)$ & \\
\hline
\end{tabular}

The study revealed that risk increases with advancing age as shown by the highly significant $p$ value of $<0.001$.

Table-3: Site affected by an LRINEC risk score.

\begin{tabular}{|l|l|l|l|l|l|}
\hline \multirow{2}{*}{ LRINEC risk score } & \multicolumn{3}{|c|}{ Site affected } & \multirow{2}{*}{ Total } & \multirow{2}{*}{ p-value } \\
\cline { 2 - 5 } & Lower & Upper & Scrotum & & \\
\hline$<6$ (low risk) & $22(84.6)$ & $4(15.4)$ & $0(0.0)$ & $26(100)$ & \multirow{2}{*}{0.023} \\
\hline $6-8$ (Intermediate risk) & $19(79.2)$ & $3(12.5)$ & $2(8.3)$ & $24(100)$ & \\
\hline$>8$ (High risk) & $4(40.0)$ & $1(10.0)$ & $5(50.0)$ & $10(100)$ & \\
\hline Total & $45(75.0)$ & $8(13.3)$ & $7(11.7)$ & $60(100)$ & \\
\hline
\end{tabular}

In the present study, it is found that the most common site affected is the lower extremity, as revealed by the significant $p$-value of 0.023 .

Table-4: Association of co-morbidities with the LRINEC risk score.

\begin{tabular}{|c|c|c|c|c|c|}
\hline \multirow[t]{2}{*}{ CO-morbidity } & \multicolumn{3}{|c|}{ LRINEC Risk Score } & \multirow[t]{2}{*}{ Total } & \multirow{2}{*}{ value } \\
\hline & $\begin{array}{l}<6 \text { (low } \\
\text { risk) }\end{array}$ & $\begin{array}{l}\text { 6-8 (Intermediate } \\
\text { risk) }\end{array}$ & $\begin{array}{l}>8 \text { (High } \\
\text { risk) }\end{array}$ & & \\
\hline Diabetes Mellitus & $2(12.5)$ & $8(50.0)$ & $6(37.5)$ & $\begin{array}{l}16(10 \\
0)\end{array}$ & \multirow{3}{*}{0.003} \\
\hline PAD & $1(11.1)$ & $3(33.3)$ & $5(55.6)$ & $\begin{array}{l}9 \\
(100)\end{array}$ & \\
\hline $\begin{array}{l}\text { Immuno } \\
\text { compromised }\end{array}$ & $0(0.0)$ & $0(0.0)$ & $1(100.0)$ & $\begin{array}{l}1 \\
(100)\end{array}$ & \\
\hline
\end{tabular}

\begin{tabular}{|l|l|l|l|l|}
\hline Bedridden & $0(0.0)$ & $1(25.0)$ & $3(75.0)$ & $4(100)$ \\
\hline Fracture & $0(0.0)$ & $1(33.3)$ & $2(66.7)$ & $3(100)$ \\
\hline
\end{tabular}

It was observed that high-risk patients are associated with more comorbid conditions as revealed by the significant $p$-value of 0.003 and the most common comorbid condition is Diabetes Mellitus.

Table-5: Diagnosis based on LRINEC score.

\begin{tabular}{|l|l|l|l|l|}
\hline \multicolumn{1}{|c|}{ Diagnosis } & \multicolumn{1}{|c|}{$\begin{array}{c}\text { Low } \\
\text { Risk }\end{array}$} & \multicolumn{1}{|c|}{$\begin{array}{c}\text { Intermediate } \\
\text { Risk }\end{array}$} & $\begin{array}{c}\text { High } \\
\text { Risk }\end{array}$ & \multicolumn{1}{|c|}{ Total } \\
\hline Necrotizing Fasciitis & $16(42.1)$ & $13(34.2)$ & $9(23.6)$ & $\begin{array}{l}38 \\
(63.3 \%)\end{array}$ \\
\hline $\begin{array}{l}\text { Non -Necrotizing } \\
\text { Infections }\end{array}$ & $\begin{array}{l}10 \\
(45.45)\end{array}$ & $11(50.0)$ & $1(4.5)$ & $\begin{array}{l}22 \\
(36.7 \%)\end{array}$ \\
\hline Total & $26(43.3)$ & $24(40.0)$ & $10(16.7)$ & $60(100 \%)$ \\
\hline
\end{tabular}

In correlation with the LRINEC score, necrotizing fasciitis was seen in 16 patients of the low-risk group, 13 patients of the intermediate-risk group and 09 patients of the high-risk group.

Table-6: Sensitivity, specificity, PPV and NPV of LRINEC SCORE for necrotizing fasciitis (cut off of 6 ).

\begin{tabular}{|l|l|l|l|l|}
\hline $\begin{array}{c}\text { LRINEC } \\
\text { Score }\end{array}$ & \multicolumn{1}{|c|}{ NF+ } & \multicolumn{1}{|c|}{ NF- } & Total & \\
\hline$>6$ & $22(57.9)$ & $12(54.5)$ & $\begin{array}{l}34 \\
(56.7\end{array}$ & $\begin{array}{l}\text { PPV 64.70\% } \\
(22 / 34 * 100)\end{array}$ \\
\hline$<6$ & $16(42.1)$ & $10(45.5)$ & $\begin{array}{l}26 \\
(43.3\end{array}$ & $\begin{array}{l}\text { NPV38.46\% } \\
(10 / 26 * 100)\end{array}$ \\
\hline Total & $38(63.3)$ & $22(36.7)$ & $\begin{array}{l}60 \\
(100)\end{array}$ & \\
\hline & $\begin{array}{l}\text { Sensitivity 57.89\% } \\
(22 / 38 * 100)\end{array}$ & $\begin{array}{l}\text { Specificity 45.45\% } \\
(10 / 22 * 100)\end{array}$ & & \\
\hline
\end{tabular}

When LRINEC Score > 6 was taken as a cut off positive predictive value was found to be $64.70 \%$, and the negative predictive value was $38.46 \%$.

Table-7: Sensitivity, specificity, PPV and NPV of LRINEC Score for necrotizing fasciitis (cut off of 8).

\begin{tabular}{|c|c|c|c|c|}
\hline $\begin{array}{l}\text { LRINEC } \\
\text { Score }\end{array}$ & NF+ & NF- & Total & \\
\hline$>8$ & $9(23.7)$ & $1(4.5)$ & $10(16.7)$ & $\begin{array}{l}\text { PPV } 90 \% \\
(9 / 10 * 100)\end{array}$ \\
\hline$<8$ & $29(76.3)$ & $21(95.5)$ & $50(83.3)$ & $\begin{array}{l}\text { NPV } 42 \% \\
(21 / 50 * 100)\end{array}$ \\
\hline Total & 38 (63.3) & $22(36.7)$ & $60(100)$ & \\
\hline & $\begin{array}{l}\text { Sensitivity } 23.68 \% \\
(9 / 38 * 100)\end{array}$ & $\begin{array}{l}\text { Specificity } 95.4 \% \\
(21 / 22 * 100)\end{array}$ & & \\
\hline
\end{tabular}


When Score $>8$ was taken, sensitivity drops down to $23.66 \%$ and specificity increased to $95.04 \%$.

Positive predictive value is $90.00 \%$ and the negative predictive value is $42.00 \%$.

\section{Table-8: Systemic complication with an} LRINEC Risk score.

\begin{tabular}{|c|c|c|c|c|}
\hline \multirow[t]{2}{*}{ Systemic complication } & \multicolumn{3}{|c|}{ LRINEC score } & p- \\
\hline & $\begin{array}{l}<6 \text { (low } \\
\text { risk) }\end{array}$ & $\begin{array}{l}6-8 \\
\text { (intermediate } \\
\text { risk) }\end{array}$ & $\begin{array}{l}>8 \text { (high } \\
\text { Risk) }\end{array}$ & value \\
\hline Acute renal failure & 0 & 3 & 1 & \\
\hline Septic shock & 0 & 1 & 5 & 0.002 \\
\hline $\begin{array}{l}\text { Multiple organ dysfunction } \\
\text { syndrome (MODS) }\end{array}$ & 0 & 0 & 3 & \\
\hline
\end{tabular}

It was found that Systemic complication was in the intermediate and high-risk case, no one in low-risk case.

The distribution was highly significant with a $\mathrm{p}$-value of 0.002 .

\section{Table-9: Association of treatment given with} LRINEC score.

\begin{tabular}{|l|l|l|l|l|l|}
\hline \multirow{2}{*}{ Treatment } & \multicolumn{3}{|c|}{ LRINEC risk score } & \multirow{2}{*}{ Total } & \multirow{2}{*}{-value } \\
\cline { 2 - 5 } & Low & Intermediate & High & & \\
\hline Conservative & $19(90.5)$ & $02(5.5)$ & $0(0.0)$ & $21(100)$ & \\
\hline Debridement & $06(26.0)$ & $13(36.11)$ & $04(21.05)$ & $23(100)$ & \multirow{2}{*}{0.002} \\
\hline Fasciotomy & $01(5.9)$ & $09(25.00)$ & $07(36.80)$ & $17(100)$ & \\
\hline Amputation & $0(0.0)$ & $0(0.0)$ & $02(10.52)$ & $02(100)$ & \\
\hline Skin grafting & $0(0.0)$ & $07(19.44)$ & $03(15.78)$ & $10(100)$ & \\
\hline Secondary Suturing & $0(0.0)$ & $05(13.88)$ & $03(15.78)$ & $08(100)$ & \\
\hline
\end{tabular}

Surgical intervention was the mainstay of management in the intermediate and high-risk category with debridement (36.11\% vs $21.05 \%)$, fasciotomy $(25 \%$ vs $36.80 \%)$, skin grafting $(19.44 \%$ vs $15.78 \%)$ and secondary suturing (13.88\% vs $15.78 \%)$.

Table-10: Mortality with an LRINEC risk score.

\begin{tabular}{|c|c|c|c|c|c|}
\hline \multirow[t]{2}{*}{ Mortality } & \multicolumn{3}{|c|}{ LRINEC Risk Score } & \multirow{2}{*}{ Total } & \multirow{2}{*}{$\begin{array}{c}\mathrm{p}- \\
\text { value }\end{array}$} \\
\hline & $\begin{array}{l}<6 \text { (low } \\
\text { risk) }\end{array}$ & $\begin{array}{l}\text { 6-8 (Intermediate } \\
\text { risk) }\end{array}$ & $\begin{array}{l}>8 \text { (High } \\
\text { risk) }\end{array}$ & & \\
\hline Mortality & $0(0.0)$ & $0(0.0)$ & $5(100)$ & $5(100)$ & \\
\hline mo & $26(47.3)$ & $24(43.6)$ & $5(9.1)$ & $\begin{array}{l}55 \\
(100)\end{array}$ & $<0.001$ \\
\hline Total & $26(43.3)$ & $24(40.0)$ & $10(16.7)$ & $\mid \begin{array}{l}60 \\
(100)\end{array}$ & \\
\hline
\end{tabular}

No mortality was found in the intermediate or lowrisk group patients.

The distribution was highly significant with a p-value
Of $<0.001$.

Table-11: Duration of hospital stay with an LRINEC risk score.

\begin{tabular}{|l|l|l|l|}
\hline \multicolumn{1}{|c|}{ LRINEC Risk Score } & Mean & \multicolumn{1}{|c|}{ Std. Deviation } & p-value \\
\hline$<6$ (low risk) & 7.08 & 3.058 & \multirow{2}{*}{$<0.001$} \\
\cline { 1 - 3 } 6-8 (Intermediate risk) & 12.00 & 3.244 & \\
\hline$>8$ (High risk) & 15.30 & 3.401 & \\
\hline Total & 10.42 & 4.450 & \\
\hline
\end{tabular}

It was found that hospital stay increases with increasing the risk of the disease

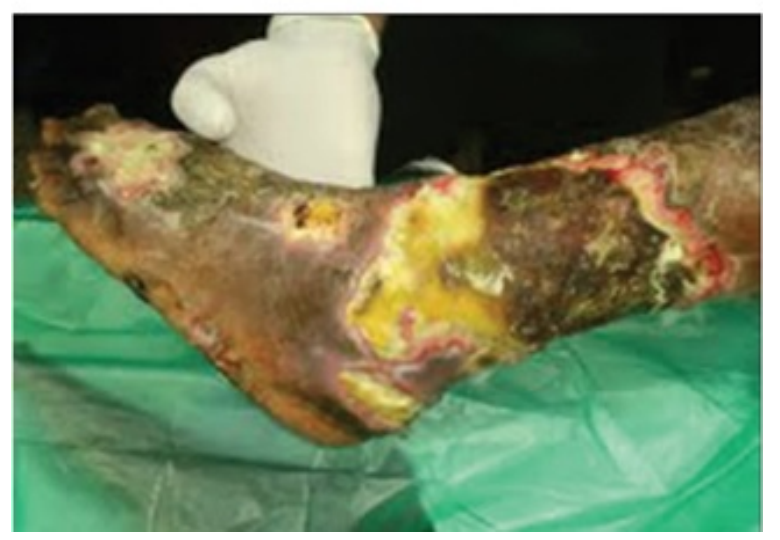

Fig-1: Necrotizing fasciitis of the left lower limb.

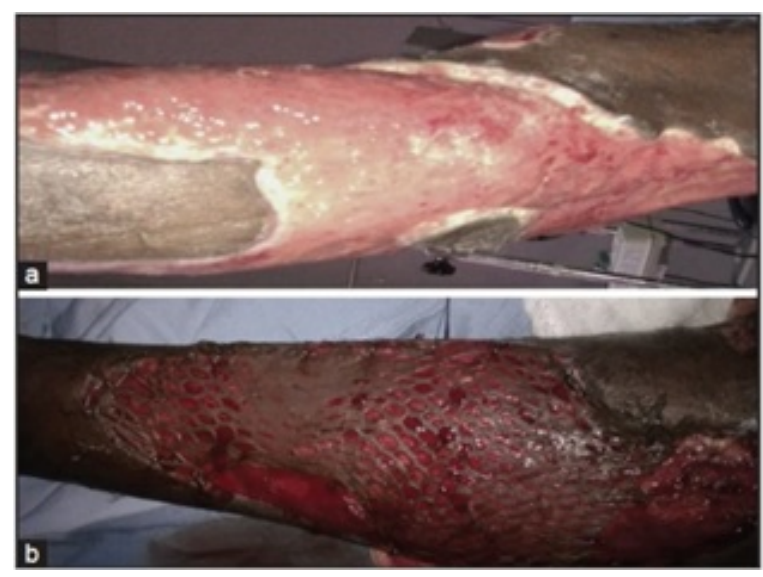

Fig-2: a-Healthy granulation tissue. b-Grafting.

\section{Discussion}

In the present study, patients were categorized using LRINEC score which is based on a fixed set of investigation parameters. Those having LRINEC score $<6$ were categorized as low risk, between 6 8 as intermediate, and $>8$ as high risk.

In all, $43.3 \%$ of the patients belonged to low risk group, $40 \%$ to intermediate, and $16.7 \%$ to high-risk 
Group. Also, its seen that males significantly outnumbered females and the soft tissue infections were commonest in the 31-40 age group. Hence, it was found that the risk profile increases with advancing age as revealed by the significant $p$-value of $<0.001$. Ayman El-Menyar et al reported that when compared to Group 1 (LRINEC $<6$ ), patients in Group 2 (LRINEC $\geq 6$ ) were five years older (mean age $53.1 \pm 15.7 v s$. $48.4 \pm 14.9$ years, $p=$ 0.009). [4].

In the present study, the most common site involved was Lower Extremities (75\%), followed by Upper Extremities (13.3\%) and Scrotum (11.7\%). The scrotum was mainly involved in patients with high-risk scoren in the present study Avalahalli et al also reported lower limb as the commonest site for necrotizing soft tissue infections ( $86 \%$ cases) in their study of 50 patients [5].

Kumar et al found that the most common site affected by the disease was lower limbs (68.33\%) which is in agreement to findings of the present study [6]. In the present study, the pain was the commonest symptom and present in all the patients $(100 \%)$. In a similar study by Soitkar et al [7], pain and swelling were the main presenting symptoms of necrotizing infection and fever was the next commonest symptom

In the present study, out of 16 diabetic patients, the majority had intermediate or high risk (50.0\% and $37.5 \%)$. Similarly, other co-morbidities were also found to be commonly associated with a high-risk group like PAD (55.6\%), bedridden patients (75\%), fracture $(66.7 \%)$ and immune-compromised patient $(n=1)$.

The distribution was highly significant with a $\mathrm{p}$-value of 0.003.A previous study by Ayman El-Menyar et al [4] reported that Diabetes Mellitus is the most common comorbidity ( 61.4 vs $41.5 \%, p<0.001$ ); others were hypertension (46.8 vs. $21.5 \%, p=$ $0.001)$; and renal disease (20.3 vs. $10.0 \%, p=$ 0.02).

The LRINEC score was first proposed by Wong et al in 2004 with the purpose of distinguishing NF and other soft tissue infections using routine biochemical tests. Based on his study, the cut-off value of 6 showed PPV of $92 \%$ and NPV of $96 \%$. [2]. In the present study, when taking LRINEC score cut-off at ' 6 ', the sensitivity is $57.89 \%$, specificity $45.45 \%$, positive predictive value $64.7 \%$ and negative predictive value $38.4 \%$ in the diagnosis of necrotizing infections.
When a cut-off score of ' 8 ' is taken, sensitivity drops down to $23.66 \%$ but specificity increased to $95.04 \%$. Positive predictive and negative predictive values were $90.00 \%$ and $42.00 \%$ respectively. These are similar to the results achieved by AlHindawi et al [8] and Liao et al [9] with the sensitivity reported as $43.2 \%$ and $59.2 \%$ respectively.

It is clearly seen from the above observations that the LRINEC scoring system is not reliable for differentiating NF from other types of soft tissue infections. A low sensitivity exposes the patient to delay in diagnosis and treatment. Receiver operating characteristic curve (ROC) for both the cut-offs also show the area under the curve less than one, suggesting LRINEC score unreliable to diagnose NF at an early stage.

A retrospective study by Neeki et al indicated that the LRINEC score may prove inaccurate when used in the emergency department for necrotizing fasciitis risk stratification and the differentiation of cellulitis from necrotizing fasciitis [10].

On correlating systemic complications of soft tissue infections with LRINEC score, it was found that patients of the high-risk group had more sepsisrelated complications. This distribution is highly significant with a $\mathrm{p}$-value of 0.002 . Similar findings on morbidity were reported by Ayman El-Menyar et al, Wong et al, and Chan et al [11] where the higher incidence of complications was present in the highrisk patients.

In the present study, it was found that almost three fourth of the patients in low-risk group were managed conservatively $(73.07 \%)$, while most of the patients of the intermediate and high-risk group required surgical intervention. Only 02 patients in the intermediate-risk and none of the patients in the high-risk group could be managed conservatively.

Most common surgical intervention required in the intermediate or high-risk group was debridement and/or fasciotomy (30 out of 34 patients), with a good proportion of them requiring secondary skin grafting or suturing (18 out of 34 patients). Amputation was required only in 02 of the patients that too in the high-risk category.

From the data, it can be clearly seen that surgery is the mainstay of treatment in severe soft tissue infections based on LINREC score, especially necrotizing infections. In the present study, mortality was most common in the patients of the 
High-risk group, and 05 out of 10 patients died during the course of treatment. The distribution was highly significant with a $p$-value of $<0.001$. This shows that an aggressive treatment plan can be instituted in a timely manner. Also, rates of mortality ( $21 \%$ vs. $11 \%)$ and amputation (36\% vs. $17 \%$ ) in patients with LRINEC score $\geq 6$ were higher than those who had LRINEC $<612$. The duration of hospital stay increases with increasing risk of the disease as revealed by the highly significant $p$-value of $<0.001$ In line with the findings of the present study, Ayman El-Menyar et al reported that the duration of stay in ICU and hospital were significantly longer among patients with higher scores.

The laboratory variables used to calculate LRINEC scoring are found to correlate individually with the diagnosis of NF in some studies such as T. Goh and L G Goh [13]. It can be concluded that high CRP, raised WBC, low haemoglobin, and high level of serum creatinine are strong indicators of necrotizing fasciitis. The study by Thomas Borschitz demonstrated that differences in CRP, elevated creatinine, decreased haemoglobins are strong indicators and levels of serum sodium and glucose are of less value as indicators of NF.

\section{Limitations}

Small sample size, Patients not giving consent for the study and those having localized infection only in the form of an abscess. Also due to lack of investigation data study is limited. Furthermore, prospective studies need to be done.

\section{Conclusion}

Necrotizing fasciitis is an aggressive disease that requires urgent therapeutic intervention to improve patient outcome and it needs to be differentiated from other soft tissue infections that have a more indolent course. From the present study, it can be concluded that LRINEC score, using readily available laboratory data, can serve as a simple and an important tool in predicting the prognosis and risk stratification in cases of necrotizing fasciitis. Sepsisrelated complications, the requirement of surgical intervention, duration of hospital stay, and mortality were found to have a significant correlation with high LRINEC score. As far as diagnostic efficacy is concerned, the LRINEC score was found to be unreliable when used solely to distinguish NF with other soft tissue infections. It has a high rate of false neqatives, low sensitivity and low positive
Predictive value.

\section{What does the study add to the existing knowledge}

Further prospective studies are probably needed to support and validate our findings. After conducting this study successfully, the conclusion can be made that LRINEC score can be used as a good prognostic indicator but its diagnostic efficacy is not reliable.

\section{Author's contribution}

Dr. Neeraj Bansal and Dr. Nitin Garg designed the present study. Dr. Neeraj reviewed literature, collected data, performed the statistical analysis and drafted the manuscript. Both authors have reviewed and edited the manuscript.

\section{Reference}

01. Lancerotto L, Tocco I, Salmaso R, Vindigni V, Bassetto F. Necrotizing fasciitis: classification, diagnosis, and management. J Trauma Acute Care Surg. 2012;72(3)560-566.

doi: [Article] [Crossref]

02. Wong CH, Khin LW, Heng KS, Tan KC, Low CO. The LRINEC (Laboratory Risk Indicator for Necrotizing Fasciitis) score- a tool for distinguishing necrotizing fasciitis from other soft tissue infections. Crit Care Med. 2004;32(7)1535-1541.

doi: [Article] [Crossref]

03. Majeski J, Majeski E. Necrotizing fasciitisimproved survival with earlyrecognition by tissue biopsy and aggressive surgical treatment. Southampt Med J. 1997;90(11)1065-1068. doi: [Article] [Crossref]

04. El-Menyar A, Asim M, Mudali I N, Mekkodathil A, Latifi $\mathrm{R}, \mathrm{Al}-\mathrm{Thani} \mathrm{H}$. The laboratory risk indicator for necrotizing fasciitis (LRINEC) scoring- the diagnostic and potential prognostic role. Scand J Trauma Resusc Emerg Med. 2017;25(1)28. doi: [Article] [Crossref]

05. Avalahalli MG, Muniraja PK, Khalid MS, Kaverappa K, Devaraj L, Rao A. Comparative study of LRINEC score- procalcitonin and LRINEC score: C-Reactive Protein in predicting duration of hospital stay and severity in necrotizing fascitis. J Evolution Med Dent Sci. 2016;5(51)3348-3351.

doi: [Article] [Crossref] 
06. Kumar N, Garg R, Soni RK, Namdeo R. Correlation of the laboratory risk indicators for necrotizing fasciitis (LRINEC) score with the clinical features and surgical management of necrotizing soft tissue infections. Int Surg J. 2018;5(10)3394-3398.

doi: [Article] [Crossref]

07. Soitkar A, Akhtar M, Choudhari A, Deshmukh S. Necrotizing fasciitis- diagnostic and prognostic value of laboratory risk indicator for necrotizing fasciitis score. Int Surg J. 2019;6(5)1750-1755. doi: [Article] [Crossref]

08. Al-Hindawi A, McGhee J, Lockey J, Vizcaychipi M. Validation of the laboratory risk indicator for necrotising fasciitis scoring system (LRINEC) in a Northern European population. J Plast Reconstr Aesthet Surg. 2017;70(1)141-143. doi: [Article] [Crossref]

09. Liao CI, Lee YK, Su YC, Chuang $\mathrm{CH}$, Wong $\mathrm{CH}$. Validation of the laboratory risk indicator for necrotizing fasciitis (LRINEC) score for early diagnosis of necrotizing fasciitis. T zu Chi Med J. 2012;24(2)73-76.

doi: [Article] [Crossref]
10. Neeki MM, Dong F, Au C, Toy J, Khoshab N, Lee $\mathrm{C}$, et al. Evaluating the Laboratory Risk Indicator to Differentiate Cellulitis from Necrotizing Fasciitis in the Emergency Department. West J Emerg Med. 2017;18 (4)684-689. doi: [Article] [Crossref]

11. Chan T, Yaghoubian A, Rosing D, Kaji A, de Virgilio $C$. Low sensitivity of physical examination findings in necrotizing soft tissue infection is improved with laboratory values- a prospective study. Am J Surg. 2008;196(6)926930.

doi: [Article] [Crossref]

12. Su YC, Chen HW, Hong YC, Chen CT, Hsiao CT, Chen IC. Laboratory risk indicator for necrotizing fasciitis score and the outcomes. ANZ J Surg. 2008;78(11)968-972.

doi: [Article] [Crossref]

13. Goh T, Goh LG, Ang CH, Wong CH. Early diagnosis of necrotizing fasciitis. $\mathrm{Br} \mathrm{J}$ Surg. 2014;101(1)e119-e125.

doi: [Article] [Crossref] 